\title{
Rom och Wittenberg eller Lima och Tokio? Nya tolkningar av kristen tro.
}

\author{
Av Lena Holmén, högskoleadjunkt i religionsvetenskap
}

\section{Länk till presentation av Lena Holmén}

\author{
"Lägg örat till marken \\ och lyssna till ljuden runt omkring. \\ Först hör du bara \\ brådskande, oroliga steg, \\ rädslans steg i mörkret, \\ förtvivlans och upprorets steg. \\ Ännu hör du inte några hoppfulla steg. \\ Men pressa örat ännu hårdare mot marken, \\ håll andan, lyssna noga: \\ Mästaren är på väg. \\ Du hör honom kanske mindre \\ när allt är som det skall \\ än i de tunga och osäkra stegens \\ svåra timmar."
}

En dikt av Dom Helder Camara, den brasilianske ärkebiskop som blivit en symbol för de många människor som brottas med och försöker tolka sin utsatthet och vanmakt utifrån ett bibliskt-kristet perspektiv. Det är människor i en livssituation som präglas av maktlöshet, fattigdom, förtryck och utanförskap av olika slag.

På 60-och 70-talen startade en rad rörelser bland marginaliserade grupper världen över. De krävde, med större kraft än tidigare, att få bli sedda och räknade med som fullvärdiga människor både ekonomiskt och religiöst-kulturellt. Dessa var bl.a. Latinamerikas fattiga massor, jordlösa och maktlösa. Nordamerikas slavättlingar och Sydafrikas förtryckta majoritet. Och detsamma gällde också de afrikaner över hela den afrikanska kontinenten som i nya fria stater under dessa decennier, från att ha varit förtryckta icke-människor, nu skulle vara subjekt i sin egen historia.

I dessa rörelser har ofta kristna ledare, som står på deras sida, spelat en stark roll i frigörelsekampen. Vi har exempel som Dom Helder Camara (nyss nämnd) och Oscar Romero, Martin L.King förstås och Julius Nyerere. Vi kan nämna Allan Boesak och Desmond Tutu och andra.

Och den här frihetskampen är en process som fortfarande pågår, och tydligast ser vi det kanske idag i Sydafrika, där de mäktiga nu tvingats dela sin makt med de förut maktlösa, och där kristna ledare agerar med kraft i den nya statens uppbyggnadsarbete. Också förra årets nobelpristagare, biskop Belo från Öst-Timor, är en kraftfull representant för sitt folks frihetssträvan. Jag tänker nu försöka att mycket sammanfattande tala om några av de livstolkningsförsök och teologier som vuxit fram i dessa grupper - under, i, och i samband med, kampen för frihet och mänsklig värdighet.

Bakgrunden är förstås Rom och Wittenberg (som angetts i rubriken) dvs den romerskkatolska och de protestantiska kyrkor som formats i det Västerland, som nu kallar sig Europa. Dessa kyrkor har i århundraden funnits utöver världen, ofta mer allierade med kolonisatörer och förtryckare än med folket (även om lysande undantag finns). 
Men det som har hänt i områden, där befrielserörelser har haft stark förankring i kristen tro, är att man har lagt åt sidan den västerländska kristendomens dogmatik och teologi, och istället tagit sin utgångspunkt direkt i bibeln. (Och det är i och för sig inget nytt: s.k. "Independent Churches" i Afrika har sedan länge gått till väga på samma sätt.) Maktlösa, marginaliserade, exploaterade, förtryckta och fattiga grupper i olika delar av världen har skapat sin egen teologi - direkt från bibeln, utan omvägen över den konstantinskaristoteliska teologi som kommer från Rom och Wittenberg. Kristen tro har på så sätt fått ge nya tolkningsnycklar åt livet och tillvaron. Med bibeln som utgångspunkt står människor i dialog med sin egen historiska situation - med den tid som är nu, och i dialog med de omständigheter de själva lever i. De utgår från sin egen kontext och detta sätt att skapa teologi kallas just kontextualisering, ett ord som återkommer flera gånger i min framställning.

De teologier, som jag nu ganska kort kommer att beröra, är Latinamerikas befrielseteologi, svart teologi och asiatisk teologi. Feministteologin tillhör förstås samma kategori, men den behöver mer tid och egen tid för att kunna belysas till fullo.

År1968 samlades Latinamerikas biskopar i Medellin i Colombia, och dokumentet från den konferensen blev basen för befrielseteologin. Mötet var en protest mot Rom, mot att den katolska kyrkan inte tydligt tog ställning i rättvise- och fredsfrågor. Biskoparna fann stöd i Andra Vatikankonciliet, som hållits 1962-65, och vars sociallära uttalade sig om människans värdighet och behovet av strukturella förändringar. Biskoparna var också bl.a. påverkade av den protestantiska teologi som växt fram i Tyskland med förintelsens lidande som bakgrund. (Jürgen Moltman, med sin "Hoppets Teologi", är en av de främsta företrädarna för denna.)

Den latinamerikanska befrielseteologin är en kritik mot allt som skapat de fattigas fattigdom: mot strukturer (rika markägare etc), mot institutioner - och också mot den moderna kristendomen. Här finns även ett stråk av marxism, särskilt det som understryker vikten av omdaning och förändring.

Befrielseteologin är en egen tolkning av kristendomen i dialog med det fattiga Latinamerikas kontext. Det är en vision om kärlek och solidaritet praktiserad bland, och tillsammans med, de fattiga. Det handlar mer om att göra teologi än att skriva, och så har också befrielseteologin växt fram: i s.k. baskommuniteter, på gräsrotsnivå.

Ett exempel, från ett slumkvarter i Lima, där katekisten (lekmannaledaren) hörs fråga:

"Varför utvalde Gud just Israel till sitt eget folk? - Det berodde på att Israel den gången var ett förtryckt och förslavat folk. Ett sånt folk är Guds eget folk! Och vilket är då Guds folk idag? Jo, precis som på Mose tid: de förtryckta, förödmjukade och förslavade. Det är gruvarbetarna, lantarbetarna, folket i stans utkantskvarter. Det är vi. Det är inga andra än vi, och alla såna som vi. De fattiga, och de som de rika struntar i! Och vad sa Gud till sitt folk genom Mose? Jo, gå ut ur det där förbannde slaveriet. Det är min heliga vilja att ni skall lämna eländet i Egypten. Och han säger samma sak till oss: Organisera uttåget. Organisera er mot Farao! Börja marschen mot ett bättre land, här i Peru. Men vad sa Farao när folket ville befria sig? Han sa nej, nej och åter nej. Och ni vet väl vilka som är faraoner idag? Det är presidenter och ministrar och generaler, och ovanför sig har dom en Överfarao i Nordamerika. Och faraonerna idag säger nej till Guds folk, precis som i forntiden. Då blir frågan till oss: Skall vi lyda Gud eller Farao? - Naturligtvis skall vi lyda Guds röst. Det är ju honom vi tror på, eftersom vi är kristna och har Bibeln. Framtiden hör till Guds folk, och Gud är revolutionens Gud."

Och många i församlingen instämmer nickande. En allmän känsla av "Gud med oss" var förnimbar, berättar en svensk teolog som var med. Flera deltagare började diskutera hur gudsfolkets utmarsch skulle se ut, och villrådigheten var ganska stor. Men efterhand vara 
man eniga om att man måste organisera sig, så många som möjligt, kring en rad konkreta krav: vattenförsörjning, rättvisare dragning av två busslinjer, återanställning av ett antal arbetare som avskedats $\mathrm{p} g$ a strejk, osv. I den situation av maktlöshet som här rådde, framstod såna aktioner som avancerade, ja revolutionära. Och människor hade befriats att vara aktiva subjekt $i$ sin egen historia!

Så bestäms också innehållet i denna nya teologi just av metaforen befrielse. Befrielse är nyckelordet som ger nya infallsvinklar och nya omvälvande tolkningar åt invanda och slitna teologiska begrepp. Synd t.ex, vad det nu betyder för Rom och Wittenberg, så betyder det här i befrielseteologin en radikal förvrängning av verkligheten - och resultatet av denna förvrängning bärs av historiens fattiga. Befrielse från orättfärdiga strukturer är nödvändig för både rika och fattiga. Och den befrielsen är en del av frälsningen. Vad det nu betyder i Rom och Wittenberg, så hör det här i befrielseteologin samman med den historiska verkligheten: Frälsning är befrielse till att vara människa på nya sätt, med Kristus som förebilden - han som lider, just som en av de förtryckta, i solidaritet med de fattiga. De ser honom som Befriaren, som strävar tillsammans med dem mot förändring i det liv och den tillvaro de lever i, inte i någon annan hinsides värld.

Därför finns det politisk sprängkraft i denna kristendomstolkning: många har fått sätta livet till i den här kampen för rättvisa och mänsklig värdighet - den mest kände martyren är väl den salvadoranske ärkebiskopen Oscar Romero, som sköts framför altaret under pågående mässa.

Dagens främste företrädare för befrielseteologin är Gustavo Gutierrez från Lima i Peru. Han har använt kristendomens klassiska begrepp för att ge röst åt de fattigas erfarenheter. Han har visat hur värderingar av makt, dominans och orättvisa har kunnat ligga inbyggda i traditionell kristendom. Och här finns en del av befrielseteologernas bidrag till vår tids teologi: de har förändrat och skärpt många kristna begrepp, och de vill få dem som inte är fattiga att lyssna till de fattigas röst. En röst som bryter in och ifrågasätter, vänder upp och ner på övertygelser och avslöjar många inbyggda kontroll- och förtryckarmekanismer i traditionella dogmatiska formuleringar.

Och Rom har inte tigit stilla. Befrielsebiskopar har systematiskt ersatts med konservativa sådana, och befrielseteologer har mist sin rätt att undervisa. Det mest uppmärksammade fallet är Leonardo Boff, men också Gutierrez har beskurits i sin verksamhet.

På 70-talet får befrielseteologerna samtalspartner från andra delar av världen där diskriminerade grupper också gör sina röster hörda. Ett forum för ekumeniska och globala teologiska samtal kommer till stånd i och med bildandet av EATWOT (Ecumenical Association of Third World Theologians).Här skrivs och debatteras nu en mängd teologiska böcker och uppsatser från olika håll. EATWOT har blivit en samtalsplats för teologer som tidigare arbetat oberoende av varandra. Deras dialog har förstärkt och bekräftat de gemensamma erfarenheterna av utanförskap och vanmakt, detta som gett bakgrunden till ny teologi om befrielse.

Representanter för Svart teologi i Nordamerika och i Sydafrika, liksom asiatiska teologer, har fått ge och ta emot nya impulser här.

Nordamerikas svarta har ju en lång tradition av egna kyrkor, och alltifrån Negro Spirituals ett arv som uttrycker den bibliska tron på ett eget sätt. I vår tid tvingades kyrkoledare att formulera sig i den medborgarrätts- och icke-våldsrörelse som leddes av Martin Luther King. Som en av de första skrev James H. Cone "God of the oppressed", "Black theology" m.fl. Nu legitimerades principen om kontextualisering. De svartas historiska och sociala kontext bestämmer både de teologiska frågorna som ställs och de svar som ges. Svart teologi gör, precis som befrielseteologin, en "re-lectura": dvs den läser om bibeln, och får där andra svar än de vedertagna. De ser Gud som de diskriminerades försvarare och befriare, och detta ger impulser till förändring, som räknar också med förtryckarnas befrielse! 
Det sagda står också för Sydafrika. För trots sin tradition med många oberoende kyrkor och teologier, var det först på 70-talet som man här började utarbeta en konsekvent svart teologi. Såväl de politiska händelserna, med det skärpta läget efter Sharpeville och Soweto, som samtalen i EATWOT bidrog till detta.

Detta var en teologi som var förankrad i den plågsamma apartheid-kontexten, men som genomsyrades av kreativitet och kritiskt tänkande. Den tvingade också kyrkor, som tidigare undvikit att engagera sig i samhällsfrågor, att nu ändra sig och tänka om.

Det viktigaste inlägget i denna teologiska process var det s.k. kairos-dokumentet. kairos är grekiska, och betyder "den rätta tiden" (för handling). Detta dokument gav uttryck för en handlingens teologi som öppet kritiserade det som var osant och orätt i apartheidsamhället, och översatt till många språk spreds det över hela världen.

Ett av dokumentets viktigaste begrepp är försoning - en försoning grundad i sanningen, men också ett försonande lidande och ett fasthållande vid icke-våld. En försoning för både svarta och vita. Vi känner till flera av dem som varit med och formulerat denna teologi och nu hör vi om dem ganska ofta i samband med rapporter från sanningskommissionen, den statliga kommission som inrättades 1995 för att reda upp de brott som begåtts under apartheid-regimen.

\section{Asien}

Det som nu först länkar nya asiatiska teologier samman med det föregående är den kontextuella tolkningsprincipen. Men också dessa är teologier som vuxit fram i reflektion över fattigdom och förtryck. Asiatisk teologi är starkt social, och knuten till den asiatiska verkligheten sådan den är på olika håll i Indien, Taiwan, Korea eller Japan. Också här vill man söka egna svar på den bibliska förkunnelsen och framför allt hitta vägen in i den asiatiska spiritualiteten.

Asien har gett många impulser till det globala samtalet i EATWOT.

Stanley Samartha är indier, professor i Bangalore och präst i den Sydindiska kyrkan. Han har arbetat vid Kyrkornas Världsråd i Geneve med dess dialog-projekt. Samartha har formulerat en Kristus-teologi i Indiens mång-religiösa samhälle. Han säger själv att uppgiften i Indien varken är att "hinduisera" kristendomen eller att kristna hinduismen. Men han tar sin utgångspunkt i sanskrit-begrepp för att utveckla sin teologi, och tar inte omvägen över något semitiskt tankemönster ur bibeln. Viktigt för honom är att Kristus är helt obunden, och inte kan identifieras med någon särskild kulturell situation eller bindas vid ett särskilt tankesystem.Tolerans och dialog finns inbyggt i Samarthas teologi om den obundne Kristus, men det är en religionsdialog som inte ger upp den kristna identiteten.

Längre i sin kontextualisering går en taiwanesisk teolog, Choan-Seng Song. Han ser Israel och kyrkan bara som symboler för hur Gud kan verka bland andra folk. Dessa folk kan också vara konstruktiva delar i, och centra för, Guds handlande. (jfr i Gamla Testamentet hur Deutero-Jesaja ser på Cyrus / Kores). Gud kan, enligt Song, inte tvingas in i ett speciellt folks (Israels) eller i kyrkans historia. Asien har sitt eget Exodus/uttåg och sin egen befrielse. "Ordet blev asiatiskt kött", säger Song, med en hänvisning till Joh.ev. kap 1 om det gudomliga skaparord som blev människa i Kristus. Denna sin radikala kontextualisering, kallar han för transponering.

Nu till sist till Tokio, och japanen Kosuke Koyama. Särskilt intressant är Koyamas dialog med buddhismen och hans intresse för hur den moderna tiden inverkar på det asiatiska samhället. Den snabba tekniska utvecklingen, ekonomi och marknad fordrar en ny socialetik som ännu inte finns, säger Koyama. Han tar itu med de etiska frågorna där de dyker upp i samhället, och detta i en sorts praktisk dialogmetod, där han använder bibeltexter in i den asiatiska kontexten.

Koyamas teologi är färgstarkt biblisk, och han uttrycker sig ofta på ett originellt och eget 
sätt. Det finns inget självsäkert i hans teologi, som är social och etisk - i stället ifrågasätter han hela tiden. Han talar om avguderiet i den moderna världen, dvs. de själviska intressen, som skapar nutidens stora girighet. Och detta - avguderi och girighet - är utgångspunkten i hans kritik av det moderna industriella samhället. Han talar om hur mening underordnas effektivitet, och om ett destruktivt självförhärligande där makt och rätt blandas samman. Och han talar om hur man i vår tid försöker höja det ändliga över det oändliga, i vad han ser som försök till självfrälsning.

I denna praktisk-etiska dialog med sin samtidskontext, blir lösningen för Koyama en korsoch lidandesteologi. Han talar om en stapplande, plågad och ofri Kristus-närvaro i Asien. Den korsfäste Kristus är svaret och närvaron - han är "den arbetslöse guden" som möter människan någonstans där ute i periferin.

I dialogen med buddhismen är kopplingen till girighet hans viktigaste tema. Han menar att just buddhismen här har ett bidrag till vår tid, genom sin starka inriktning på att övervinna girighet. En av hans böcker heter "Mount Fuji and Mount Sinai", och där säger han:

Förhållandet mellan buddhism och kristendom inte är ett förhållande mellan "sann religion" eller "falsk religion". Det handlar om två olika, men ändå sammantvinnade, sätt att se på den mänskliga girighetens historia.

Koyama talar, liksom många andra av Tredje världens teologer, rakt in i vår tids kontext. De bidrar med en vital och nyskapande bibelteologi, som har sin plats i den verklighet som är deras. Och de behöver bli lyssnade till, inte minst av Rom och Wittenberg, för dessa är i sin kristendomstolkning låsta i en dialog som fördes med hellenismen för 2000 år sedan och när de försöker föra en dialog sig emellan, ligger brytpunkten i en kontext som går 400 år tillbaka i tiden! Impulser från den kontextualisering in i vår tid, som pågår bland teologer i Tredje världen, är därför särskilt viktiga för en vitalisering av västerländsk kristendom.

(Föredrag hållet 971022) 